Synthesis, part of a Special Feature on The Conservation and Restoration of Old Growth in Frequent-fire Forests of the American West

\title{
Old-growth Policy
}

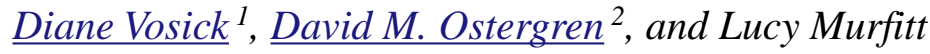

\begin{abstract}
Most federal legislation and policies (e.g., the Wilderness Act, Endangered Species Act, National Forest Management Act) fail to speak directly to the need for old-growth protection, recruitment, and restoration on federal lands. Various policy and attitudinal barriers must be changed to move beyond the current situation. For example, in order to achieve the goal of healthy old growth in frequent-fire forests, the public must be educated regarding the evolutionary nature of these ecosystems and persuaded that collaborative action rather than preservation and litigation is the best course for the future of these forests. Land managers and policy makers must be encouraged to look beyond the single-species management paradigm toward managing natural processes, such as fire, so that ecosystems fall within the natural range of variability. They must also see that, given their recent evidence of catastrophic fires, management must take place outside the wildland-urban interface in order to protect old-growth forest attributes and human infrastructure. This means that, in some wilderness areas, management may be required. Land managers, researchers, and policy makers will also have to agree on a definition of old growth in frequent-fire landscapes; simply adopting a definition from the mesic Pacific Northwest will not work. Moreover, the culture within the federal agencies needs revamping to allow for more innovation, especially in terms of tree thinning and wildland fire use. Funding for comprehensive restoration treatments needs to be increased, and monitoring of the Healthy Forest Initiative and Healthy Forest Restoration Act must be undertaken.
\end{abstract}

Key Words: diameter caps; federal employee liability; institutional barriers; Mexican spotted owl; northern goshawk; preservationist philosophy; public education; wildland fire use

\section{INTRODUCTION}

Understanding the history of forest management and attitudes toward forest resources are a prerequisite to understanding the changes needed in current policies to promote old growth. Motivating policy change to support recruitment and protection of old growth requires that the public, federal agencies, business interests, and elected officials understand and agree that managing for old growth is important and that old growth is an essential component of a healthy forest ecosystem.

A complex relationship exists between the public, policy makers, stakeholders, and the land management agencies when it comes to developing and implementing public policy. A common assumption is that policy will be based on rigorous science, data, and other factual information. As a result, a great deal of attention is devoted to the development and distribution of that information as a primary strategy to catalyze change. However, Congressional legislation and agency regulations are created in response to a variety of influences that include individual constituents, lobbyists, interest groups, economic conditions, public opinion, and social values, to name a few (Oleszek 2001). Frequently, the promulgation of policy is a response to an immediate, cataclysmic event that captures the attention of the public, who in turn demand action (Downs 1972).

A recent example of this was the exponential increase in funding for the National Fire Plan (NFP) in federal fiscal year 2001, which was a direct and immediate response by Congress to one of the worst fire years in the United States' history. Looking further back in history, one finds that the catastrophic fires in the Lake States during the latter decades of the $19^{\text {th }}$ century and the great fires of 
1910 in the West gave rise to the fire-suppression policies that have contributed greatly to today's forest health problems. Thus, although science is important, in reality, the scientific basis for a policy is just one of many factors that influence the final decision. In the end, policies reflect social values that are informed by many factors, including science.

In this chapter, we analyze current federal policies in the context of the scientific recommendations for old-growth protection and recruitment, and the policy and attitudinal barriers that must be changed to achieve old-growth management goals. The proposed changes will build from the logic and scientific evidence presented in previous chapters, yet recognize that, in the final analysis, human values will carry the day.

\section{THE POLICY AND SOCIAL CONTEXT OF OLD-GROWTH PROTECTION SINCE THE $1960 S$}

Most federal policies do not explicitly include old growth, yet protection of old growth has dramatically influenced forest management for the past 35 years. Understanding how advocates for protection of old growth have used a variety of laws to influence and change federal land management is necessary to identify what policy changes may be needed to restore old growth. In fact, rigorous protection strategies may not be appropriate to restore old-growth conditions in the frequent-fire forests of the western United States.

As detailed in the article by Alexandra Murphy and colleagues (2007) in this special issue, timber resources were aggressively harvested to support economic expansion and home construction following World War II. During the 1970s and 1980s, clearcutting increased to all-time highs throughout the national forest system (Yaffee 1994). A modern environmental consciousness came of age during the same period, inspired by the work of biologist Rachel Carson in the 1960s, and reflected in the popular culture by the celebration of the first Earth Day in April 1970. The growing awareness of conservation, and increasing demand for the protection of air and water quality, wildlife, and wild places began to collide with commoditydriven forest management during this period.

\section{Congress Codifies Environmental Protection}

Before the 1960s, the general public and the federal courts had little involvement in management decisions of the Forest Service. However, during the 1960s and 1970s, popular demand for the conservation and protection of public lands and wildlife led Congress to pass laws that codified environmental protection and broadened public involvement in land-management decisions. Some of the most significant statutes expanded the rights of citizens and advocacy groups to legal recourse in federal land-management issues (Keele et al. 2006). These decisions enabled citizens and advocacy groups to successfully use administrative appeals and other legal actions to influence landmanagement decisions. The Administrative Appeals Reform Act of 1993 affirmed this right of appeal.

During the 1960s and 1970s, Congress passed the Wilderness Act, the National Environmental Policy Act (NEPA), the Endangered Species Act (ESA), the Federal Land Policy and Management Act (FLPMA), and the National Forest Management Act (NFMA). Each statute addressed the public's demand for environmental protection and the need for new approaches to manage natural resources. Despite no specific mention of old growth, these five acts are the foundation for decisions that influence old-growth management today.

Congress passed the NFMA to create a new framework of greater accountability and transparency for forest-management decisions. During Senate hearings on the NFMA, Senator Hubert Humphrey observed that the Forest Service's record had brought into question the extent to which the agency could be relied upon to protect and manage public resources. Humphrey declared:

The days have ended when the forest may be viewed only as trees and trees viewed only as timber. The soil and the water, the grasses and the shrubs, the fish and the wildlife, and the beauty that is the forest must become integral parts of resource managers' thinking and actions. (Gifford Pinchot Task Force 2006). 
The NFMA and its implementing regulations are the primary legal framework for managing national forests. Congress intended that National Forest plans would guide forest management and provide the public with transparent standards and guidelines for management. Congress also provided the Forest Service with clear guidance in terms of implementing the NFMA. Specifically, section 3(B) became the basis for advocates to argue that oldgrowth protection was inherent in maintaining the diversity of plant communities and, therefore, was afforded protection under the NFMA.

The regulations shall include, but not be limited to....

(3) specifying guidelines for land management plans developed to achieve the goals of the Program which-

(A) insure consideration of the economic and environmental aspects of various systems of renewable resource management, including the related systems of silviculture and protection of forest resources, to provide for outdoor recreation (including wilderness), range, timber, watershed, wildlife, and fish;

(B) provide for diversity of plant and animal communities based on the suitability and capability of the specific land area in order to meet overall multiple-use objectives, and within the multiple-use objectives of a land management plan adopted pursuant to this section, provide, where appropriate, to the degree practicable, for steps to be taken to preserve the diversity of tree species similar to that existing in the region controlled by the plan.... (16 U.S.C. $§ 1604(\mathrm{~g})$.)

Congress passed the NEPA to ensure that environmental considerations, along with economic and technical considerations, are factored into decisions made by federal agencies. The Forest Service used the NEPA to evaluate the first forest plans and their subsequent amendments. The 2005 Forest Planning Rule eliminated the internal requirement to do an Environmental Impact Statement (EIS) as a part of forest planning, However, on 29 May 2007, the United States District Court for the Northern District of California issued a decision in combined cases involving the Forest Service. The Court held that the adoption of the 2005 Planning Rule violated the Administrative Procedure Act (APA), the NEPA, and the ESA. It enjoined the agency from implementing or otherwise using the rule (USDA Forest Service 2007). Exactly how forest planning will proceed is unclear at this time.

The interface between the NFMA, National Forest Plans, and the NEPA created transparency for the public to monitor proposed management actions. It was the intersection of these three policies that created the pathway for concerned organizations and individuals to challenge forest management decisions (Keele et al. 2006). It was the concern about endangered species listed under the ESA and the relationship of those species to forest practices (in particular, the removal of old growth) that mobilized the environmental community to take legal action whenever the Forest Service appeared to have ignored administrative procedure or noncommodity values.

Using these laws as the primary tool for challenging land-management decisions has generated controversy. Some policy makers believe that the NEPA process has been abused to obstruct land management (General Accounting Office (GAO) 2003), whereas others maintain that the NEPA is inadequately applied to guide decisions (Lindstrom and Smith 2001). In some cases, environmental organizations have resorted to challenging administrative minutia in order to further their goals. Whether this is because federal agencies failed to address important management issues (e.g., biodiversity) or because some environmental organizations are overzealous in their efforts is a matter of opinion. The fact is that both sides have won and lost cases, and legal actions have had a significant effect in terms of changing the process of decision making used by the Forest Service (Manring 2003).

\section{A CASE STUDY: HAWKS, OWLS, AND FOREST PLANS CONVERGE TO INFLUENCE MANAGEMENT OF FORESTS IN THE SOUTHWEST}

Forest plans in the Southwest Region were completed from 1985 to 1988, before the Mexican spotted owl (Strix occidentalis lucida) was listed under the ESA and before there was active public concern about the apparent decline in northern goshawk (Accipiter gentilis) populations. Although the plans addressed habitat needs for threatened, endangered, and sensitive species by articulating some guidelines, they included little specific 
guidance for the two species that would become the basis for significant litigation. Forest plans that were completed in the $1980 \mathrm{~s}$ continued to promote silviculture and sustained-yield forestry as the primary objective of forest management. Early forest plans emphasized a sustained-yield, evenaged management system based on the removal of large and old trees, and replanting or reestablishment of trees to unnaturally high levels of uniform ages and sizes (USDA Forest Service 1995). In the 1990s, even-aged forest management and wood production started to give way to ecosystem management and the need to change management to provide for more diverse ecological and social values (Cortner and Moote 1999).

The issues of forest management, forest planning, and protection of critical habitat for endangered, threatened, and sensitive species under the ESA erupted in the Southwest in 1995 when federal Judge Carl Muecke ordered logging to stop in all Southwest federal forests in response to a lawsuit by the Center for Biological Diversity (Anderson 1995).

Conservation of the northern goshawk had already caught the attention of the Forest Service, who chose to list it in the Southwest as a "sensitive species" in 1982 (Reynolds et al. 1992). During initial forest plan development in the mid-1980s, five of the plans provided for a 20- to 30-acre protection area around occupied northern goshawk nests. The type and extent of habitat needed for these two species, and forest management practices that threatened that habitat, became the issue that focused attention on land management by the federal agencies. These two wildlife species provided a foundation to argue for the protection of old growth.

In order to save the goshawk and the forests it depends upon, the Center for Biological Diversity has launched an ambitious campaign to protect all three subspecies and all mature forests from Alaska to Mexico. At the federal level, the Center is seeking to list the Queen Charlotte goshawk as an endangered species in Alaska, British Columbia, Washington and Oregon, and the Apache and Northern Goshawks as endangered species in all U.S. States west of the continental divide. At the regional level, the Center is leading efforts to protect goshawks in the Southwest, the Sierra Nevada, Utah, and Southeast Alaska. At the local level, we are challenging timber sales, grazing allotments, and road construction which destroys goshawk habitat. The Center is also conducting scientific research on goshawks and publishes an online review of goshawk research and conservation issues. (Center for Biological Diversity 2006.)

On 24 June 1992, the Forest Service filed a Notice of Intent to prepare an EIS amending all 11 Forest Management Plans in the Southwest Region to incorporate guidelines for habitat management of the northern goshawk and the Mexican spotted owl. The EIS created an avenue for the Center for Biological Diversity and others to challenge the goshawk guidelines, maintaining that the guidelines were based on the incorrect assumption that the northern goshawk is a "habitat generalist" that uses a variety of different habitats. The Center, along with the Arizona Department of Game and Fish and the U.S. Fish and Wildlife, instead argued that the northern goshawk is an old-growth "forest specialist" that depends on old-growth forests (United States Court of Appeals for the Ninth Circuit 2003).

The final EIS (FEIS) evaluating alternatives for Forest Plans in Region 3 adopted an alternative that responded to comments taken from the Mexican Spotted Owl Recovery Plan (MSORP), which was released in March 1995. The FEIS included standards and guidelines based on the MSORP and the standards and guidelines developed by the Interagency Scientific Committee for northern goshawks. This alternative recommended retention of $50 \%$ of trees in mature and old forests. Since adoption of the forest plan amendments in 1996, managers have largely avoided locating projects in habitat for Mexican Spotted Owl (protected activity centers or PACs) and have either avoided treatments in northern goshawk post-fledgling family areas (PFAs) or faced controversy.

\section{FUEL AND FIRES INCREASE IN FREQUENT-FIRE FORESTS}

Between 1986 and 2003, timber-processing capacity in the Southwest plummeted by $63 \%$ (Keegan et al. 2004). Timber harvest levels likewise declined dramatically from an average high in the 1980s of 402 million board feet (MMBF) to 46 
MMBF by 1996 . By 1996 , the harvest had shifted almost exclusively to fuelwood (Raisch et al. 1997). Although there were early signs that the economics and feasibility of commercial logging in the Southwest were waning, the 1995 injunction by Judge Muencke accelerated the decline of logging in the region. The timber industry in Arizona, New Mexico, Colorado, and Utah depended on timber from federal land for $70 \%$ of their supply, leaving them particularly vulnerable to changes in forest policy.

Fire suppression and other historic management actions have led to an unnatural increase in the amount of fuel in frequent-fire forests. The net annual growth (NAG) of sawtimber (NAG = annual growth - [harvest + mortality + defect]) on timberland in the Southwest Region results in a net annual increase of $461 \mathrm{MMBF}$. Structural changes include significant increases in the number of trees that are $<43.2(<17$-in) $\mathrm{cm}$ in diameter at breast height (dbh; Johnson 1994). This unnatural stocking of small trees, combined with other compositional and structural changes in the forest, set the stage for unprecedented crown fire outside the natural range of variability for frequent-fire forests.

\section{Catastrophic Fire Triggers New Policies: the Healthy Forest Initiative and Restoration Act Seek to Expedite Treatments while Protecting and Restoring Old Growth}

As a result of the increasing severity, size, and frequency of catastrophic fire, the federal agencies and Congress initiated significant policy changes starting in 1995. The 2000 Cerro Grande Fire in Los Alamos, New Mexico and other unprecedented conflagrations in Montana that year provided the impetus for Congress to significantly increase funding to the federal land-management agencies through the 2000 National Fire Plan. In response to complaints that planning and the processes associated with the NEPA, NFMA, and ESA were the biggest impediments to a swift response to the wildfire crisis, President G.W. Bush advanced administrative policy changes through the Healthy Forest Initiative (HFI) in 2002. Through the HFI, the administration sought to streamline the administrative rules and regulations guiding environmental review of projects, consultation requirements under the ESA, and other procedures considered impediments to forest thinning and restoration. Congress echoed this action one year later with the Healthy Forest Restoration Act (HFRA) of 2003, which authorized up to $\$ 760$ million for restoration and fuel-reduction treatments, and made additional policy changes designed to accelerate hazardous fuel reduction (GAO 2003). In an attempt to address environmental concerns that the HFRA would accelerate potentially harmful commercial logging that might include old growth, Congress included provisions designed to protect and enhance old growth. Other significant provisions directed the Secretary of Agriculture to give priority to projects that protect at-risk communities, watersheds, or communities that implement Community Wildfire Protection Plans (CWPPs). The Act also states that no less than $50 \%$ of the funding under the Act should go to projects in the Wildland-Urban Interface or WUI (Healthy Forest Restoration Act 2003).

Defining old growth in statute is a vexing problem for congressional staff (J. Watts, Counsel to Senator Diane Feinstein, personal communication, 2006). The fact that the definition must vary by forest type, geographical location, and other ecological variables makes a statute-friendly, one-size-fits-all definition impossible. Congress elected to tie the definition of old growth in the HFRA to the provisions of the NFMA that describe goals for protecting plant and animal diversity. Tied to the provisions of the NFMA to protect diversity, the HFRA also seeks to maintain old growth and allow actions that will restore it.

In carrying out a covered project, the Secretary shall fully maintain, or contribute toward the restoration of, the structure and composition of old-growth stands according to the pre-fire suppression old-growth conditions characteristic of the forest type, taking into account the contribution of the stand to landscape fire adaptation and watershed health, and retaining the large trees contributing to old-growth structure. (Healthy Forest Restoration Act, 2003.)

Federal agencies are just beginning to use the new HFRA authorities. The House and Senate held hearings during the summer of 2006 to review agency work under the HFRA and HFI to determine the extent they are used (House Resources Committee/Forests and Forest Health Subcommittee, 29 June 29 2006; Senate Energy and Natural Resources Committee/Public Lands and Forests, 19 
July 2006). Testimony from Deputy Secretary of the Interior Lynn Scarlett indicated that use of new authorities is just beginning because of the timelines associated with existing project planning (Scarlett 2006). One witness, Matthew Koehler of the WildWest Institute, reviewed provisions related to restoring and protecting old growth in his testimony. He asserted that the Forest Service ignored the oldgrowth protection provisions in a project proposed under HFRA guidelines on the Middle East Fork in the Bitterroot National Forest (Koehler 2006). It is still too early to determine how much the provisions under the HFRA and HFI will be used, and whether or not they will be used to protect old growth.

In response to the HFRA and the support expressed by communities for protection, the agencies have focused hazardous fuels treatments in the WUI. Other factors, including the easy access to most of these WUI sites, the solid funding for hazardous fuels reduction (as opposed to that for restoration treatments) and the low likelihood of conflict, support this emphasis. Unfortunately, this preoccupation with the WUI may be coming at the cost of protecting valuable attributes in the landscape, such as old growth.

Further confounding forest restoration is the emphasis by the Office of Management and Budget and Congress on treating the maximum number of acres using the least amount of money. This has a fiscal logic, but fails to consider the associated ecological implications. This performance measure pushes the agencies toward acres that are easier to treat (acres that have not accumulated excessive fuels and, therefore, can be treated with prescribed burning as opposed to more costly thinning and burning) and militates against treating acres that may require more complex, costly approaches or are difficult to access. In the case of old growth, the need to reduce understory fuels before prescribed burning adds significant cost to the treatment. Land managers are hard pressed to meet acreage targets as well as address highest priority areas with the available dollars associated with this performance measure.

\section{WHAT THREATENS OLD GROWTH?}

In the 1990s, the biggest perceived threat to old growth was logging. The basis for this concern was legitimate-it was a response to one hundred years of high-grading the forest for the biggest and best trees as well as other management decisions that left frequent-fire forests depauperate of old growth. By the 1990s, old growth in the Rocky Mountains and Southwest had been reduced to a fraction of the amount that occurred before Euro-American settlement (Kaufmann et al. 1992b).

With a focus on protecting old growth from logging, the environmental community effectively used the policy tools of the 1970s to challenge projects that cut old growth or large trees, or appeared to negatively affect critical habitat. These actions (or threats of actions), along with the loss of sawmills capable of handling (and dependent on) largediameter trees and the loss of harvest infrastructure, have significantly reduced the number of forest treatment projects that include old-growth forests or large trees. To provide assurance that old growth will not be cut, collaborative forestry groups often argue for and obtain a diameter-size limit (or cap) on the size of trees that can be removed (Friederici 2003). For example, Arizona maintains a de facto $40.6 \mathrm{~cm}$ (16-in) dbh cap on trees harvested from State Trust forested lands. Similarly, the first projects developed by the Greater Flagstaff Forests Partnership were designed with diameter caps. Although these caps have questionable ecological benefit, their existence has allowed some projects to move forward that might otherwise have been appealed (Abella et al. 2006).

However, if logging was the only threat to the survival of old growth in frequent-fire forests, then a qualified victory could be declared in most parts of the West. The good news is that logging is no longer the primary threat to old growth in frequentfire forests. The bad news is that a myriad of other factors threaten its survival. Solving these problems will require changes in public understanding, federal land-use policy, and agency culture.

\section{WHAT NEEDS TO CHANGE? PUBLIC UNDERSTANDING, FEDERAL POLICY, AND AGENCY CULTURE}

A successful strategy to retain and promote old growth in frequent-fire forests requires broader acceptance that active management is necessary. To develop this acceptance will take time and the political will to act. 


\section{Public Understanding: Retaining and Recruiting Old Growth Requires Action- Hands-off Preservation Will Not Work}

All frequent-fire, old-growth forests have been influenced by humans (Pyne 1982, Kaufmann et al. 1992b). Fire by indigenous people, a century of fire suppression, and grazing are but a few anthropogenic influences that have shaped the condition of old growth for millennia.

People have an emotional attachment to old growth. These feelings arise from the sense that old-growth forests are static, venerable, and unchanged for long periods (Sharpe et al. 1986). Given this perception, many people believe that, by leaving old-growth forests alone, they will be preserved.

\section{A common perception is that actively managing old growth is inappropriate or incompatible with other values, resulting in proposals to set aside mature and old- growth forests and prohibiting any form of management. However, even where non- timber values are primary, active management of mature and old-growth forest may be necessary to promote and/or sustain ecological values over time. (Society of American Foresters 2005.)}

Old growth in frequent-fire forests evolved with low- and mixed-severity fire. Although the landscape was believed to be dominated by old growth before Anglo-European settlement, multiaged and sized trees were an important, dynamic element associated with old-growth structure (Covington and Moore 1994). Frequent fire meant the herbaceous layer in an old-growth stand was constantly changing, that tree recruitment was sporadic - the site was dynamic, not static.

Preservationist, hands-off, anti-logging strategies were a rational protection strategy when logging was the biggest threat to old growth. It is not the strategy that will protect old growth today (Thomas 2006). It is only through active restoration and management that old growth will be protected and recruited. However, restoring old growth requires an evaluation of whether restoration is a one-time affair or includes re-entry over predetermined timeframes, and whether wildfire will be allowed to burn or whether prescribed burning will be used.
A necessary approach to build confidence in management decisions will be to bring stakeholders into management discussions through collaboration (Friedman 2006). Most federal, state, and regional policies of the last 6 years promote collaboration as a way to build trust between citizens and the agencies (Western Governors' Association 2001, 2002; HFRA 2003). This activity, although no guarantee for smooth and quick conflict resolution, is proving to decrease acrimony and build understanding for forest restoration (Lowe and Moote 2005).

\section{Action:}

- Federal land-management agencies should continue to integrate collaboration in landmanagement decision making. To do this successfully requires training, clarity of purpose and roles, and transparency. It should also be supported through collaborationbased performance measures. Veterans of collaboration do not feel agency personnel are adequately trained or supported to achieve success (Moote and Becker 2003). The agencies should continue to emphasize the importance of collaboration, and provide the training to do it effectively.

\section{Federal Policy: Intelligently Managing for Old Growth Requires an Understanding of the Underlying Evolutionary Framework of Frequent-fire Forests}

Restoring forest health requires understanding the evolutionary forces that shaped frequent-fire forests. Although it is difficult to understand all the drivers and nuances of complex ecosystems, ecological restoration approaches assume that by understanding and restoring the major functions, structure, and composition of an ecosystem, the ecosystem will be launched on a trajectory that will return it to its natural range of variability. This approach to management is a radical departure from the views embraced and promoted by forest managers in most of the $20^{\text {th }}$ century, and is theoretically supported by an improved understanding of dynamic ecology and ecosystems (Christensen et al. 1996, Pickett et al. 1997, Cortner and Moote 1999). 
Action:

- Continuing education - with an emphasis on emerging knowledge of forest ecosystemsshould be encouraged for land managers.

\section{Federal Policy: Retention and Recruitment of Old Growth Is an Essential Part of Any Strategy to Improve the Ecological Health and Resiliency of the Whole Forest}

Managers should move beyond single-species objective management and manage for the natural processes-such as fire-that support multiple ecosystem attributes.

Managing for only one or few ecosystem elements often leads to unintended consequences. A more holistic approach is more likely to lead to overall ecosystem sustainability in the long term. Furthermore, conservation biologists and restorationists agree that most native biological diversity, including threatened species and endangered resources, will be supported when an ecosystem is restored to its natural range of variability (Noss et al. 2006).

\section{Action:}

- Forest plans should establish a central goal of restoring ecological processes and the natural range of variability to frequent-fire forests. Forest plan revisions should acknowledge the importance of restoring ecological processes to achieve multiple biodiversity objectives. They should also acknowledge that, in many cases, it will be necessary to mechanically alter stand structure as well as encourage understory development that will support surface fire. Restored forests will support retention and recruitment of old growth.

- Clarify the goshawk guidelines for the management and environmental communities. The goshawk guidelines (Reynolds et al. 1992) influence management activity in the Southwest more than any other region in the country. The guidelines emphasize the importance of retaining old growth while restoring historic forest structure. Emerging work demonstrates that treatments using the goshawk guidelines and those using forest health restoration treatments developed by the Ecological Restoration Institute are largely consistent (Richard T. Reynolds and $\mathrm{W}$. Wallace Covington, personal communication, 2006). However, there is widespread misinterpretation of the guidelines by practitioners with respect to establishment of openings and tree-selection criteria. In many cases, practitioners fail to create adequate size openings, and misinterpret desired forest structure. Efforts to clarify the goshawk guidelines and move treatments in the direction of comprehensive restoration should become the cornerstone of future training activities for forest managers in the Forest Service.

- Wildland fire use plans should be completed. Restoring natural fire to the landscape is essential to recruit old growth. Wildland fire use plans should be completed so that, where and when appropriate, natural ignitions can be used to reduce hazardous fuels. However, overstocked old-growth stands should be identified during the planning process and thinned of hazardous fuels before reintroducing fire. Fire-management officers and others will need the support of regional and national offices to help protect them from the potential liabilities and negative publicity inherent in the use of wildland fire.

- Pass state "right-to-burn" statutes. Florida passed legislation that grants landmanagement agencies the right to use fire for management purposes. Concern exists that the federal Clean Air Act and the Americans with Disabilities Act may lead to a prohibition or serious restrictions on burning. The right of land-management agencies to use this tool may need preemptive protection by statute. The most difficult aspect of right-to-burn statutes will be defining airshed pollution allotments that include regular forest fires. In the San Joaquin Valley of California, air pollution is such that Yosemite and Kings Canyon national parks have been forced to cancel fires because smoke and particulate matter would exceed local standards. 
Federal Policy: Healthy Forest Restoration Act - Hazardous Fuel Reduction Must Go Outside the Wildland-Urban Interface to Protect Irreplaceable Forest Attributes

Agencies are compelled to focus hazardous-fuel reduction treatments in the WUI to protect communities. This choice minimizes conflicts with the environmental community and addresses immediate public concerns about fire. However, it diverts management action from the broader landscape. Many environmental groups hope that, once the WUI is treated, the public will more readily accept using fire as the primary tool to restore forest health at the landscape level. They hope that either no thinning or only light thinning will be necessary before wildland fire use (WFU) can be employed to restore extensive forest landscapes (Nowicki 2002).

The priority for forest managers in the Southwest should be to provide the greatest possible degree of protection to interface communities through joint-fuels reduction programs.... Once communities in the forest interface are reasonably protected, FOREST GUARDIANS believes that fire must become a viable forest management tool. In order for people to feel safe, their immediate surroundings must be treated, local fire departments must be adequately funded and adequate evacuation routes must exist and be identified. (Byrd and Brittenburg 2005.)

When fuel reduction and restoration treatments focus solely on communities, many attributes in the broader landscape are compromised and remain vulnerable to damage and mortality caused by unnatural, severe fire. Support exists for treatments to protect important elements of the landscape (Arizona Governor's Forest Health Advisory Council 2004).

Action:

- Treatments should occur outside the WUI to protect and restore important landscape attributes. The HFRA permits up to $50 \%$ of the authorized funding to be spent outside the WUI. The federal land-management agencies should work with communities to identify acres for treatments that protect landscape attributes including old growth, watersheds, and critical habitat.
- The federal agencies should use the authorities provided under the HFRA to protect and restore old growth from catastrophic fire. Using this authority will require full engagement through collaboration, a difficult but not impossible task. By implementing the policy designed to protect old growth, the agencies can build the trust required to reduce hazardous fuels and improve health of old growth in frequent-fire forests.

\section{Federal Policy: Performance Measures for Treatments Should Be Modified to Encourage Quality, Not Just Quantity}

Not all acres cost the same to treat, nor are all acres equally important. The current emphasis of maximizing the number of acres treated drives the federal agencies to treat "cheap" acres, not necessarily the most important acres. Revising performance standards so that strategic and priority acres (such as those that protect old growth and bolster community protection) are emphasized and treatments that provide for the return of surface fire are rewarded. Such a policy will encourage actions that are more ecologically significant and economically prudent.

Action:

- Congress and the Office of Management and Budget should recognize that maximizing the number of acres treated per unit cost is an insufficient measure of agency performance to determine treatment effectiveness. The land management agencies should develop performance measures that support efforts to treat important acres.

\section{Federal Policy: Management to Protect and Recruit Old Growth May Be Needed in Some Wilderness Areas}

Some federally designated Wilderness Areas and National Park Service (NPS) backcountry areas are irreplaceable reservoirs of biological diversity. 
However, fire suppression and the ecological degradation associated with fire interruption may leave these areas vulnerable to catastrophic fire. Managed treatments within the framework of the law may be needed in these areas to preserve or restore their wilderness character (Ostergren 2006).

\section{Action:}

- Initiate careful restoration treatments to protect old growth in Wilderness Areas and NPS backcountry areas where irreplaceable biodiversity attributes are threatened.

\section{Federal Policy: the Definition for Old Growth in Frequent-fire Forests Is Not the Same as the Definition for Old Growth Developed in the Pacific Northwest}

The definition of old growth in frequent-fire forests has been confounded by attempts to align it with definitions of old growth in the mesic forests of the Pacific Northwest. In fact, definitions of old growth developed in the Southwest that were derived from the Northwest characterizations and observations of post-settlement structure in the Southwest (Kaufmann et al. 1992a) bear little resemblance to old-growth trees and stands before AngloEuropean-induced changes as described by current research (Covington and Moore 1994). This confusion has undermined management strategies for frequent-fire forests and confounded policy makers.

\section{Action:}

- Definitions of old growth for frequent-fire forests should be developed, peer reviewed, and adopted by the federal agencies.

\section{Federal Policy: Increase Funding for Comprehensive Restoration Treatments}

Presently two-thirds of funding provided through the National Fire Plan is dedicated to fire suppression. Only one-third is dedicated to preventative action. Studies demonstrate that it makes economic and ecological sense to invest in preventing rather than suppressing unnatural wildfires (USDA Office of the Inspector General, Western Region 2006, Snider et al. 2006).

Restoration treatments reduce hazardous fuels and simultaneously restore forest health. Nonetheless, many land managers don't acknowledge this fact, and focus primarily on hazardous-fuel reduction. Many managers justify their decision based on the belief that funding exists primarily for hazardousfuel reduction.

\section{Action:}

- The federal land-management agencies should clarify that comprehensive restoration treatments qualify for hazardous-fuel reduction dollars.

- Congress and the Office of Management and Budget (OMB) should increase federal landmanagement agency capacity to review and conduct restoration treatments across the landscape.

\section{Federal Policy: the Environmental Review Process}

Congress and the Administration have changed the environmental review processes that were perceived as slow and obstructionist. Congressional hearings in 2006 indicate that those processes are just beginning to be applied and it is unclear how well the changes have achieved their objectives of reducing appeals and accelerating action.

\section{Action:}

- Congress should monitor application of the environmental review process to see if the goals promulgated in the HFI and HFRA are achieved.

- Congress should fund the public outreach and project planning activities sufficiently to rebuild trust in federal agencies among all interest groups. 


\section{Agency Culture}

There is little incentive to reward federal land managers who innovate. Moreover, in the face of diminished financial and human resources for land management, agency personnel often default to familiar actions that avoid controversy or do not require additional time.

These institutional realities influence management in many ways. For example, many managers do not reduce fuels adequately to allow the safe reintroduction of low-intensity fire. This occurs for several reasons. First, hazardous-fuel reduction treatments in frequent-fire forests may still reflect past practices that sought to enhance commercial wood production rather than restore ecological health. Therefore, too many trees are left in patterns reminiscent of tree farms rather than natural ecosystems. Second, managers are responding to public pressure to limit the size and number of trees harvested. Third, in attempts to address interdisciplinary concerns, treatment objectives may be confounded by trying to address such concerns as wildlife habitat and visual effects, thus diluting the effectiveness of treatments. These factors conspire to reduce the efficacy of treatments and their long-term effectiveness for wildfire risk reduction and forest restoration.

Risk aversion also diminishes the use of wildland fire. Fire is inherently risky, both ecologically and from a public relations perspective. For example, the escape of the 2006 Warm Fire on the North Kaibab National Forest attracted negative media coverage and public concern. Nevertheless, use of natural ignitions has proved effective in the Gila National Forest and elsewhere in the Southwest. Wildland fire use requires the judgment of skilled, experienced professionals combined with scientifically sound predictive models.

\section{Action:}

- The agency should provide the training, liability protection, and encouragement required to build confidence when employing its wildland fire use authority.

\section{CONCLUSION}

Most federal policies do not directly address the protection of frequent-fire, old-growth forests. Nevertheless, during the last 30 years, protection of old growth erupted as an important conservation issue. Advocates used a number of policy tools to advance preservation, including the ESA, NEPA, the Goshawk Guidelines in Region 3 of the Forest Service, and the NFMA.

Environmental litigation and the attrition of commercial harvest infrastructure have minimized commercial logging as a threat to old growth. Of greater concern among ecologists is the potential loss of existing old growth to unnatural catastrophic fire, and the inability to effectively manage for the recruitment of old growth because of the difficulty and cost of restoring natural processes and forest structure through the application of restoration treatments.

There is widespread agreement among stakeholders that we need to restore the natural structure, functions, and composition of frequent-fire forests. However, the public will be concerned about proposals that call for treatments in and around old growth. Actively educating the public and building trust through collaboration is a necessary prerequisite before taking action. The federal landmanagement agencies will need a change in performance measures to support action in old growth. For example, agency performance with respect to treated acres should not be based on getting the most acres per unit cost. Rather, a new performance standard is needed that emphasizes quality and treatments to protect valuable attributes, which may in fact cost more per unit. Land managers should be rewarded for treatments that may initially require more time, attention, and collaboration, rather than defaulting to the easiest acres to accomplish (i.e., acres in the wildland-urban interface vs. in the greater landscape), and they should be empowered to use the tools, such as wildland fire, that will facilitate restoration and recruitment of old growth. Finally, Congress must provide the financial resources that support the level of human and financial commitment required to restore forests. 
Responses to this article can be read online at:

http://www.ecologyandsociety.org/voll2/iss2/art19/responses/

\section{Acknowledgments:}

The authors want to thank Jesse Abrams, Wally Covington, and Tom Klabunde for their thoughtful comments and insights.

\section{LITERATURE CITED}

Abella, S. R., P. Z. Fulé, and W. W. Covington. 2006. Diameter caps for thinning southwestern ponderosa pine forests: viewpoints, effects, and tradeoffs. Journal of Forestry 104(8):407-414.

Anderson, S. 1995. Owl shuts down the Southwest. High Country News 27(16). (online) URL: http://w ww.hcn.org/servlets/hcn.Article?article id=1276.

Arizona Governor's Forest Health Advisory Council. 2004. Guiding principles for forest ecosystem restoration and community protection. Phoenix, Arizona, USA. [online] URL: http://www. governor.state.az.us/FHC/documents/Final\%20Guiding\% 20Principles \%20with\%20groupings\%20and\%20authors\% 20-\%2010-03.pdf.

Byrd, B., and C. Brittenburg. 2005. Born of fire: the National Fire Plan in the southwest. Forest Guardians, Santa Fe, New Mexico, USA.

Center for Biological Diversity. 2006. Northern goshawk. Tucson, Arizona, USA. [online] URL: http://www.biologicaldiversity.org/swcbd/species/ goshawk/goshawk.html.

Christensen, N. L., A. Bartuska, J. H. Brown, S. Carpenter, C. D'Antonio, R. Francis, J. F. Franklin, J. A. MacMahon, R. F. Noss, D. J. Parsons, C. H. Peterson, M. G. Turner, and R. G. Woodmansee. 1996. The scientific basis for ecosystem management. Ecological Applications 6:665-691.

Cortner, H. J., and M.A. Moote. 1999. The politics of ecosystem management. Island Press, Washington, D.C., USA.

Covington, W. W., and M. M. Moore. 1994.
Postsettlement changes in natural fire regimes and forest structure: ecological restoration of oldgrowth ponderosa pine forests. Pages 153-182 in R. N. Sampson and D. L. Adams, editors. Assessing forest ecosystem health in the Inland West. Haworth Press, New York, New York, USA.

Downs, A. 1972. Up and down with ecology: the "issue-attention" cycle. The Public Interest 28:3850 .

Friederici, P. 2003. The Flagstaff model. Pages $7-$ 25 in P. Friederici, editor. Ecological restoration of southwestern ponderosa pine forests. Island Press. Washington, D.C., USA.

Friedman, M. 2006. The Forest Service is dead; long live the Forest Service! It's time for conservationists to collaborate with an agency they've long demonized. Grist: Environmental News and Commentary (Soapbox): 28 February 2006. [online] URL: http://www.grist.org/comments/soap box/2006/02/28/friedman/.

General Accounting Office (GAO). 2003. Forest Service: information on appeals and litigation involving fuels reduction activities. General Accounting Office GAO-04-52.

Gifford Pinchot Task Force. 2006. Bush Administration attempts to undermine forest protection rules. Portland, Oregon, USA. [online] URL: http://www.gptaskforce.org/article.php?id=120

Healthy Forest Restoration Act of 2003. Public Law 108-148, 117 Stat. 1887, 16 USC $§ \S 6501$ et seq.

Johnson, M. A. 1994. Changes in southwestern forests: stewardship implications. Journal of Forestry 92(12):16-19.

Kaufmann, M. R., W. H. Moir, and R. L. Bassett, editors. 1992a. Old-growth forests in the Southwest and Rocky Mountain regions, proceedings from a workshop. U.S. Forest Service General Technical Report RM-213.

Kaufmann, M. R., W. H. Moir, and W. W. Covington. 1992b. Old-growth forests: what do we know about their ecology and management in the Southwest and Rocky Mountain regions? Pages 111 in M. R. Kaufmann, W. H. Moir, and R. L. 
Bassett, editors. Old-growth forests in the Southwest and Rocky Mountain regions, proceedings from a workshop. U.S. Forest Service General Technical Report RM-213.

Keegan, C. E., T. A. Morgan, K. M. Gebert, J. P. Brandt, K. A. Blatner, and T. P. Spoelma. 2004. Timber-processing capacities and capabilities in the western U.S. Western Forestry Leadership Coalition, Lakewood, Colorado, USA. [online] URL: http://www.wflccenter.org/ts dynamic/ edu outreach/18 file.pdf.

Keele, D. M., R. W. Malmsheimer, D. W. Floyd, and J. E. Perez. 2006. Forest Service land management litigation 1989-2002. Journal of Forestry 104(4):196-202.

Koehler, M. 2006. Testimony before the Subcommittee on Public Lands and Forests United States Senate on Implementation of the Healthy Forest Restoration Act (Public Law 108-148). 19 July 2006. [online] URL: http:// energy.senate.gov/public/_files/Koehler.pdf.

Lindstrom M. J., and Z. A. Smith. 2001. The National Environmental Policy Act: judicial misconstruction, legislative indifference and executive neglect. Texas A \& M University Press, College Station, Texas, USA.

Lowe, K., and M. A. Moote. 2005. Collaboration as a tool in forest restoration. Working Papers in Southwestern Ponderosa Pine Forest Restoration \#11. Ecological Restoration Institute, Northern Arizona University. Flagstaff, Arizona, USA. [online] URL: https://library.eri.nau.edu:8443/hand le/2019/191.

Manring N. J. 2003. Locking the back door: the implications of eliminating postdecisional appeals in national forest planning. Society and Natural Resources 17:235-245.

Moote A., and D. Becker. 2003. Exploring barriers to collaborative forestry. Report from a workshop held 17-19 September 2003, Hart Prairie, Flagstaff, Arizona, USA. [online] URL: https://library.eri.nau. edu:8443/handle/2019/211.

Murphy, A., J. Abrams, T. Daniel, and V. Yazzie. 2007. Living among frequent-fire forests: human history and cultural perspectives. Ecology and Society 12(2): 17. [online] URL: http://www.ecolog yandsociety.org/vol12/iss2/art17/.

Noss R. F., P. Beier, W. W. Covington, R. E. Grumbine, D. B. Lindenmayer, J. W. Prather, F. Schmielgelow, T. D. Sisk, and D. J. Vosick. 2006. Recommendations for integrating biology in ponderosa pine forests of the Southwest. Restoration Ecology 14(1):4-10.

Nowicki, B. 2002. The community protection zone: defending houses and communities from the threat of forest fire. Center for Biological Diversity, Tucson, Arizona, USA. [online] URL: http://www. sw-center.org/swcbd/programs/fire/wuil.pdf.

Oleszek, W.J. 2001. Congressional procedures and the policy process. Fifth Edition. Congressional Quarterly Press, Washington, D.C., USA.

Ostergren, D. M. 2006. Wilderness management and the restoration of fire: an analysis of laws and regulations in northern Arizona. Ecological Restoration Institute, Northern Arizona University, Flagstaff, Arizona, USA. [online] URL: https://libr ary.eri.nau.edu:8443/handle/2019/365.

Pickett, S. T. A., R. S. Ostfeld, M. Shachak, and

G. E. Likens. 1997. Ecological basis of conservation: heterogeneity, ecosystems, and biodiversity. Springer, New York, New York, USA.

Pyne, S. J. 1982. Fire in America: a cultural history of wildland and rural fire. University of Washington Press, Seattle, Washington, USA.

Raish, C., W. Yong, and J. M. Marzluff. 1997. Contemporary human use of southwestern ponderosa pine forests. Pages 28-42 in W. M. Block and D. M. Finch, technical editors. Songbird ecology in southwestern ponderosa pine forests: a literature review. U.S. Forest Service General Technical Report RM-GTR-292. [online] URL: http://www.fs.fed.us/rm/pubs rm/rm gtr292/ rm gtr292 028 042.pdf.

Reynolds, R. T., R. T. Graham, M. Reiser, and M. Hildegard. 1992. Management recommendations for the northern goshawk in the southwestern United States. U.S. Forest Service General Technical Report RM-217. [online] URL: http://www.treesea rch.fs.fed.us/pubs/6420.

Scarlett, L. 2006. Testimony before the 
Subcommittee on Forests and Forest Health Committee on Resources, U.S. House of Representatives. Oversight Hearing on Healthy Forests: Targets and Accomplishments. 29 June 2006. [online] URL: http://resourcescommittee.house. gov/109/testimony/2006/lynnscarlett.htm.

Sharpe, W., C. W. Hendee, and W. E. Sharpe. 1986. Introduction to forestry. McGraw-Hill, New York, New York, USA.

Snider G., P. J. Daugherty, and D. Wood. 2006. The irrationality of continued fire suppression: an avoided cost analysis of fire hazard reduction treatments versus no treatment. Journal of Forestry 104(8):431-437.

Society of American Foresters. 2005. Managing mature and old-growth forests: a position of the Oregon Society of American Foresters. Adopted by the OSAF membership on December 2005.

Thomas, J. W. 2006. Sustaining forests. The Sacramento Bee 11 July 2006.

United States Court of Appeals for the Ninth Circuit. 2003. Center for Biological Diversity vs. USFS/R3 and Chief of the Forest Service. No. 02-16481/D.C. No. CV-00-01711-RCB/Opinion. 18 November 2003.

USDA Forest Service. 1995. Final environmental impact statement for amendment of forest plans. USDA Forest Service-Region 3, Albuquerque, New Mexico, USA.

USDA Forest Service. 2007. Southwestern Region: status of court ruling on 2005 Planning Rule. [online] URL:

http://www.fs.fed.us/r3/coconino/projects/planrevision-2006/2007-05-29-2005-planning-rule-q-a. pdf.

USDA Office of Inspector General, Western Region. 2006. Forest Service: large fire suppression costs. Audit Report No. 08601-44-SF. U.S. Forest Service, Washington, D.C., USA. [online] URL:

http://www.usda.gov/oig/webdocs/08601-44-SF.pdf

Western Governors' Association. 2001. A collaborative approach for reducing wildland fire risks to communities and the environment: 10-year comprehensive strategy. Denver, Colorado, USA. [online] URL: http://www.westgov.org/wga/initiatives/ fire/final fire rpt.pdf.

—. 2002. A collaborative approach for reducing wildland fire risks to communities and the environment: 10-year comprehensive strategy implementation plan. Denver, Colorado, USA. [online] URL: http://www.westgov.org/wga/initiatives/ fire/implem plan.pdf.

Yaffee, S. 1994. The wisdom of the spotted owl. Island Press, Washington, D.C., USA. 